\title{
Peculiarities of Plasmodium falciparum Gene Regulation and Chromatin Structure
}

\author{
Maria Theresia Watzlowik ${ }^{1}$, Sujaan Das ${ }^{2}$, Markus Meissner ${ }^{2}$ and Gernot Längst ${ }^{1, *}$ \\ 1 Department of Biochemistry, Genetics and Microbiology, Biochemistry III, University of Regensburg, \\ Universitätsstr. 31, 93053 Regensburg, Germany; Maria-theresia.watzlowik@ur.de \\ 2 Faculty of Veterinary Medicine, Chair of Experimental Parasitology, Ludwig-Maximilian-University, Munich, \\ Lena-Christ-Str. 48, 82152 Martinsried-Planegg, Germany; Sujaan.Das@para.vetmed.uni-muenchen.de (S.D.); \\ Markus.Meissner@para.vetmed.uni-muenchen.de (M.M.) \\ * Correspondence: gernot.laengst@ur.de
}

Citation: Watzlowik, M.T.; Das, S.;

Meissner, M.; Längst, G. Peculiarities of Plasmodium falciparum Gene Regulation and Chromatin Structure. Int. J. Mol. Sci. 2021, 22, 5168. https://doi.org/10.3390/ ijms22105168

Academic Editor: Tobias Straub

Received: 16 April 2021

Accepted: 10 May 2021

Published: 13 May 2021

Publisher's Note: MDPI stays neutral with regard to jurisdictional claims in published maps and institutional affiliations.

Copyright: (C) 2021 by the authors Licensee MDPI, Basel, Switzerland. This article is an open access article distributed under the terms and conditions of the Creative Commons Attribution (CC BY) license (https:/ / creativecommons.org/licenses/by/ $4.0 /)$.
Abstract: The highly complex life cycle of the human malaria parasite, Plasmodium falciparum, is based on an orchestrated and tightly regulated gene expression program. In general, eukaryotic transcription regulation is determined by a combination of sequence-specific transcription factors binding to regulatory DNA elements and the packaging of DNA into chromatin as an additional layer. The accessibility of regulatory DNA elements is controlled by the nucleosome occupancy and changes of their positions by an active process called nucleosome remodeling. These epigenetic mechanisms are poorly explored in P. falciparum. The parasite genome is characterized by an extraordinarily high AT-content and the distinct architecture of functional elements, and chromatin-related proteins also exhibit high sequence divergence compared to other eukaryotes. Together with the distinct biochemical properties of nucleosomes, these features suggest substantial differences in chromatindependent regulation. Here, we highlight the peculiarities of epigenetic mechanisms in $P$. falciparum, addressing chromatin structure and dynamics with respect to their impact on transcriptional control. We focus on the specialized chromatin remodeling enzymes and discuss their essential function in $P$. falciparum gene regulation.

Keywords: chromatin; epigenetics; Plasmodium falciparum; nucleosome; nucleosome remodeling; transcription regulation; chromatin structure

\section{Introduction}

Plasmodium falciparum, a unicellular eukaryotic parasite, causes the most severe and deadly form of the human disease malaria. In 2019, 229 million cases of malaria infection with about 409,000 deaths were reported, mainly affecting children under the age of five [1]. Malaria is still a major threat for humans and the situation may become worse as parasites increasingly develop resistance to the frontline choice of treatment, artimisinin-based combinational therapy, just as resistance to other effective drugs has emerged [2]. There is an urgent need for new antimalarial drugs, but this requires better understanding of the physiological, biochemical and pathological mechanisms of the parasite. In particular, the chromatin landscape and the epigenetic mechanisms are exceptionally different in Plasmodium, representing a potential drug target. Here, we review the specific features of Plasmodium falciparum chromatin structure.

Plasmodium spp.-- together with other parasites such as Toxoplasma-belong to the phylum of Apicomplexa, which evolutionarily separated from the human line about 8001000 million years ago [3]. The Plasmodium life cycle is complex, including two different hosts, with an asexual reproduction phase in humans and sexual reproduction in mosquitos of the genus Anopheles [4]. In humans, Plasmodium exists in intra- and extracellular forms and is capable of invading various cell types, including hepatocytes and erythrocytes. The parasite undergoes asexual reproduction and sexual commitment in the human host, 
leading to the differentiation of male and female gametocytes, which are taken up by a mosquito bite for the completion of sexual reproduction. This versatile multistage life cycle is tightly regulated with defined sets of proteins being concertedly expressed in specific phases of the life cycle. The underlying regulatory mechanisms of this highly orchestrated gene expression program in Plasmodium falciparum are poorly understood.

As a common principle, gene regulation in eukaryotes involves regulation on many levels, starting with controlling DNA accessibility within chromatin, followed by transcriptional control, post-transcriptional regulation, translational control, protein stability and activity, and additional mechanisms [5]. In this review, we will focus on Plasmodium falciparum chromatin structure and dynamics, reviewing its contribution to the regulation of gene expression and comparing it to other eukaryotes.

\section{DNA-Based Features}

\subsection{Genome and Gene Architecture}

The complete Plasmodium falciparum (Pf) genome sequence was determined in the year 2002 [6] and consists of 23.3 million base pairs, organized in 14 chromosomes plus $6 \mathrm{~kb}$ mitochondrial and $34 \mathrm{~kb}$ apicoplast DNA located in the respective cytoplasmic organelles [7]. The parasite genome features one of the most AT-rich eukaryotic genomes with an overall AT-content of $80.7 \%$ and within intergenic regions and introns of up to $95 \%$ [8]. Due to the high AT-content, the genome contains numerous low-complexity regions, simple sequence repeats and a skewed codon usage bias. It comprises a total number of 5280 protein-coding genes as well as 158 pseudogenes and 103 annotated noncoding RNAs [9]. At least 4557 of the 5280 genes are transcribed and expressed in a complex pattern depending on the life cycle stage [10], requiring a complex regulatory network.

In general, the $P f$ genome exhibits typical eukaryotic features, with genes consisting of exons and introns separated by intergenic regions. But gene architecture clearly differs from other unicellular eukaryotes by an increased mean gene length of $2300 \mathrm{bp}$ (vs. 1400 bp in Saccharomyces), an increased mean exon length of 949 bp (typically 200-300 bp in all eukaryotes) and a markedly large proportion of genes larger than $4000 \mathrm{bp}$. The sizes of introns and intergenic region usually correlate linearly with the genome size [11]. With regard to genome size, $P f$ displays unusually large intergenic regions (mean of $1700 \mathrm{bp}$ ) and introns with an average length of $180 \mathrm{bp}$, which is rather long for protists but very short in comparison to higher eukaryotes [6].

\subsection{Regulatory DNA Elements}

Like other eukaryotes, $P f$ genes exhibit the characteristic bipartite structures of cisregulatory regions with enhancer elements and basal promotors required for the recruitment of RNA polymerase II to the transcription start site (TSS) (reviewed in [12,13]). Most TSSs are relatively distant to the first exon, resulting in mRNAs with exceptionally long $5^{\prime}$ untranslated regions, with an average of $346 \mathrm{nt}$ [14], when compared to human mRNA ( 150 nt) [15]. The presence of antisense transcripts indicates the existence of bidirectional promotors with multiple shared or separate regulatory elements including the presence of multiple clusters of TSSs within a single gene locus [16]. Thus, genome-wide mapping of TSSs revealed highly diverse sets of start sites that are far more variable than those of human genes. Core promotors exhibit sequence motifs directing TSS selection and promotor strength, such as local changes in GC-content and homopolymeric nucleotide stretches (reviewed in [13]). Early on it was shown that the packaging of the promotor DNA into nucleosomes and alterations in nucleosome positioning and histone composition also influence gene activity [17-19], as will be described below.

Applying in silico approaches and algorithms, numerous putative cis-regulatory motifs could be predicted [20-22], and a few of them were experimentally validated [23]. These elements act as enhancers or silencers, as known for other eukaryotes, but $P f$ possesses an extraordinarily high number of such elements (4-5 per gene) sharing no sequence similarity with those of other eukaryotic organisms. Recent studies showed that the major- 
ity of the plasmodial genome is organized in regulatory units containing multiple genes and multiple regulatory elements with coordinated activity, rather than a one-on-one allocation of cis-regulator elements to their neighboring genes [24].

\subsection{Trans-Acting Factors}

The principle of gene expression regulation is based on the binding of specific transcription factors (TF) to cis-regulatory motifs. Surprisingly, only $73 \mathrm{TFs}$ were identified in Pf having more than 5000 genes. This is far below the numbers in yeast $(\sim 170$ TFs for 5400 genes) and human cells ( $>1500$ TFs for 20,000 genes) [25-27]. In addition, most of the major families of eukaryotic TFs, such as homeodomains, basic leucine zipper, GATA fingers, nuclear hormone receptor and FKH domains, could not be identified through a homology search [28]. The $P f$ transcription factors can be grouped into eight helix-turn-helix proteins, $37 \mathrm{C} 2 \mathrm{H} 2$-type zinc fingers and one $\beta$-scaffold factor, but all exhibit only low conservation across different Plasmodium species [13,25]. Moreover, Apicomplexa possess a novel category of TFs, the ApiAP2 family, which are presumably the main regulators of transcription in the parasite life cycle $[29,30]$.

Most of the 27 members of the ApiAP2 family were shown to exhibit sequence-specific DNA-binding [31,32]. Some of the PfApiAP2s or orthologs were shown to be essential and to drive transcriptional regulation at different stages of the life cycle [13], [33]: For example, AP2-L plays a critical role in liver-stage development [34]; AP2-G was identified to be the master regulator of gametocytogenesis [35]; AP2-I is relevant for invasion gene activation [36]; AP2-O activates gene expression in ookinetes [37], while gene expression in liver-infecting sporozoites is regulated by AP2-Sp [38]. Still the question remains, how such a low number of factors is sufficient to coordinate the complex gene expression profile of more than 5000 genes. It was suggested that TFs act in a combinatorial fashion and may exhibit pleiotropic functionality $[33,39,40]$. Alternatively, they might interact with additional regulatory proteins [36,41], or undergo post-transcriptional modification like other epigenetic regulators [42-44].

The interplay between cis-acting elements and trans-acting factors is strongly influenced by the packaging of the genomic DNA into chromatin. Nucleosome positioning and dynamics control the accessibility of the regulatory DNA elements for the trans-acting factors, as histones would mask the binding sites and inhibit DNA sequence recognition. Therefore, nucleosome-positioning plays an essential role, and well-defined chromatin architectures can be observed at regulatory regions. At gene promoters, positioned nucleosomes (+1) just downstream of the TSS can be observed, and the promoter region directly upstream is generally depleted of nucleosomes [18]. Such a structure is compatible with the binding of transcription factors, and changes to this chromatin structure would substantially affect gene activity. Genome-wide profiling using ATAC-seq identified such accessible DNA regions, mainly located in $5^{\prime}$-intergenic regions, overlapping with annotated and predicted cis-regulatory elements. These accessible regulatory regions correlate overall with high mRNA levels of the associated genes [45,46], revealing the binding of trans-activating factors to these sites. The direct effect of transcription-factor binding to transcriptional regulation was proven, but it is unclear how chromatin structure and nucleosome dynamics additionally affect and regulate the access of the trans-acting factors to their binding sites. Chromatin dynamics and nucleosome positioning may be a consequence of transcription-factor binding or represent a preceding event regulated by chromatin-remodeling enzymes that determine DNA accessibility.

\section{Chromatin features}

\subsection{Pf Nucleosomes and Their Special Properties}

Nucleosomes are the basic packaging unit of chromatin, consisting of a histone octamer associated with 147 base pairs of DNA wrapped around the proteins in 1.65 turns. The octamer consists typically of the four canonical histones H2A, H2B, H3 and H4, which are-due to their central function in DNA packaging-highly conserved in sequence 
throughout eukaryotic evolution [47]. For example, Arabidopsis thaliana $\mathrm{H} 3$ and human $\mathrm{H} 3$ differ in only two amino acids [48]. However, $P f$ histones show an extraordinarily high divergence with sequence identities of only $64 \%, 68 \%, 93 \%$ and $92 \%$ between human and Pf $\mathrm{H} 2 \mathrm{~A}, \mathrm{H} 2 \mathrm{~B}, \mathrm{H} 3$ and $\mathrm{H} 4$ respectively. The fifth histone $\mathrm{H} 1$, usually linking nucleosomes and promoting higher order structure, is not present in $P f$ [6].

In accordance with the diverging sequence of histones, plasmodial nucleosomes exhibit distinct biochemical properties when compared to human nucleosomes (see Figure 1). The Pf nucleosome exhibits reduced stability, weaker binding of $\mathrm{H} 2 \mathrm{~A}$ and $\mathrm{H} 2 \mathrm{~B}$ and has intriguingly lost the capability of DNA sequence-dependent nucleosome positioning [49].

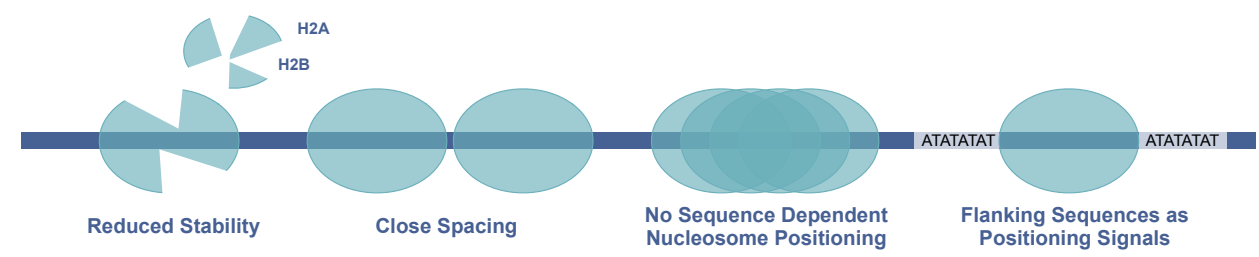

Figure 1. Schematic representation of distinct nucleosome properties in P. falciparum. In comparison with human nucleosomes, Pf nucleosomes exhibit reduced stability and short spacing between nucleosomes, and positioning is rather independent of internal DNA sequence but is determined by flanking sequence motifs.

Since DNA is not a flexible polymer but a rather rigid molecule with a persistence length of $150 \mathrm{bp}$, a deviation from this defined DNA structure would require bending energy [50]. In the context of a nucleosome, the DNA molecule has to be highly bent in order to enable wrapping around the histone octamer. The required bending energy is compensated by establishing about 400 direct and indirect ionic interactions and $\mathrm{H}$ bridges between the DNA and the histones [51]. As GC and AT base pairs do not have exactly the same size and geometry, sequence composition does affect DNA structure by inducing bents and kinks with specific sequence motifs. Repetition of such motifs every $10 \mathrm{bp}$ would induce directed DNA curvature that mimics the folding around the histone octamer, requiring less bending energy for nucleosome formation and thus, representing the preferential binding sites of nucleosomes [52]. It is a general eukaryotic principle that the genome sequence codes for a basic chromatin architecture with the base-pair sequence favoring nucleosome positioning and occupancy at specific sites [53-55]. In vitro and in vivo studies showed that nucleosome positions are in part determined by intrinsic DNA features [54]. The GC-content and the frequency of polyA-stretches and certain dinucleotide repeats turned out to be critical determinants for nucleosome positioning and occupancy and, therefore, impact the overall regulation of gene expression [56].

However, the AT-rich plasmodial genome sequence deviates substantially from other eukaryotes with respect to sequence motifs, and likewise Pf nucleosomes do not obey the classical sequence-dependent positioning rules [49]. The typical $10 \mathrm{bp}$ periodicity of anti-phased A/T and G/C dinucleotides in nucleosomal DNA [57] is only weakly detectable in P. falciparum [18], [58]. The shifted nucleotide-ratio in the Pf genome creates a very different basis for chromatin structure, and $P f$ histones show deviating affinities when forming nucleosomes. Nucleosome positioning analysis in $P f$ revealed a significant number of positioned nucleosomes in vivo, mainly located at or in the vicinity of regulatory regions, as expected for their regulatory role in determining DNA accessibility. This raises the question of the mechanisms being responsible for nucleosome positioning in vivo, even though the $P f$ histone octamer does not recognize the underlying sequence code. There are numerous mechanisms that can still contribute to nucleosome positioning in $P f$, including DNA binding factors, statistical positioning of neighboring nucleosomes by a constant DNA linker length and chromatin-remodeling factors that move and position nucleosomes [59]. For $P f$ nucleosomes it was shown that AT-repeat sequences in the DNA linker regions are sufficient to position nucleosomes. This presents a novel signal and 
mechanism for nucleosome positioning and suggests that histone linkers may interact with the linker DNA, thereby contributing to nucleosome positioning. Crystal structures of $P f$ nucleosomes are not available so far, but in silico modeling based on human nucleosomes suggests an overall similar nucleosome core structure with only a few divergent amino acids in the histone-DNA interacting regions [49]. The majority of sequence variation is located in the flexible histone tail regions, whose likely contribution to nucleosome positioning has not been proven yet. The fact is that $\mathrm{Pf}$ nucleosomes show decreased nucleosome stability overall, with weaker binding of H2A/H2B-dimer within the octamer, and an attenuated histone-DNA interaction increases the mobility of nucleosomes on DNA. The hypothesis that altered nucleosome properties evolved as an adaptation to the AT-rich plasmodial genome could be rejected. In vitro and in vivo data show that $P f$ histones like other eukaryotic histones bind preferentially to GC-rich over AT-rich DNA [49].

Besides the differences in nucleosomal properties, the nucleosome repeat length is highly divergent as well when compared to other eukaryotes. With a repeat length of $155 \mathrm{bp}$, the spacing of the nucleosome cores is maintained by DNA linkers with only $8 \mathrm{bp}$. Short nucleosome spacing is an intrinsic biochemical property of the $P f$ nucleosome, which can be observed in vitro and is maintained also in vivo [49,60]. The mean linker length in eukaryotes is significantly longer, varying from 20 to $75 \mathrm{bp}$ depending on species and cell type [61]. Such short linker lengths, as found in Plasmodium, were shown to inhibit the folding of the nucleosome array into compact higher order structures of chromatin. The absence of higher-order chromatin structure correlates well with the assumption that Pf chromatin exhibits high accessibility [49,62-64]. The extremely short linker length and unusual chromatin compaction are putative consequences of the exceptional nature of DNA composition and histone properties in $P f$.

\subsection{Histone Variation}

In addition to canonical histones, eukaryotes express histone variants throughout the cell cycle, which differ in amino acid sequence. Sequence variation occurs predominantly in the (N-)terminal histone tails and leads to novel and different sites of posttranslational modifications, potentially impacting their function and interaction with chromatin-modifying enzymes [65]. Among eukaryotic species, different sets of variant histones are prevalent, with some ubiquitous variants having specialized functions in DNA repair (H2A.X), transcription activation (H2A.Z), kinetochore formation (CenH3) and transcription in general (H3.3) [66].

In P. falciparum, a homologue of the universally present H2A.Z was identified, but no H2A.X. Surprisingly, Apicomplexa additionally express an unusual H2B variant histone, called H2B.Z, whose function is still unclear. Genome-wide profiling revealed similar binding sites of $P f \mathrm{H} 2 \mathrm{~A} . \mathrm{Z}$ and $P f \mathrm{H} 2 \mathrm{~B} . \mathrm{Z}$ and coimmunoprecipitation experiments confirmed the existence of nucleosomes containing both H2A.Z and H2B.Z in the same octamer $[67,68]$. This observation is shared with studies in other Apicomplexa, including Toxoplasma gondii, indicating a role in the regulation of gene expression (reviewed in [69]).

Histones $\mathrm{H} 3.3$ and $\mathrm{CenH} 3$, the two universal variants replacing histone $\mathrm{H} 3$, are present in P. falciparum, although they have not been characterized in detail. Histone H3.3 has eight amino acids substitutions compared to canonical H3 (one amino acid exchanged in human H3.3) and is believed to preferentially bind GC-rich repetitive regions, independent of transcriptional activity, potentially contributing to the regulation of var gene expression and immune evasion [70]. The second $\mathrm{H} 3$ variant, $\mathrm{CenH} 3$, is enriched at AT-rich sequences of the centromere and is implicated in chromosome segregation [70,71].

Histones are the target for post-translational modifications (PTMs), mainly comprising acetylation, methylation and phosphorylation of the histone amino termini, which alter histone properties and their interactions with DNA and chromatin proteins, affecting the functionality of the underlying DNA. The combinatorial nature and functional impact of these epigenetic modifications are defined as the "histones code" amplifying the information content and plasticity of chromatin with respect to the regulation of all DNA- 
dependent processes [72,73]. Here too, P. falciparum exhibits striking differences to other eukaryotes with an unusually large proportion of constitutively acetylated histones and a high number (500) of identified PTMs, including several novel modifications specific to Plasmodium or Apicomplexa $[72,74,75]$. A recent study showed, that a few universally eukaryotic PTMs, initially proposed to be absent in P. falciparum, are tightly regulated, and their presence is limited to specific life cycle stages [76]. The presence of some dynamic PTMs peaking in particular stages, such as H3K4 and H3K27 modifications, emphasize their contribution to gene-expression regulation throughout stage development $[72,76,77]$.

\subsection{Nucleosome Occupancy and Dynamics In Vivo}

Nucleosomal distribution on DNA is described by the terms "nucleosome occupancy" and "nucleosome positioning": Occupancy describes the probability with which a certain base pair is covered by a nucleosome, while nucleosome positioning is a measure of the probability of a given base pair to serve as start, dyad or end position of a nucleosome [78]

The reduced stability and loss of sequence-dependent positioning of plasmodial nucleosomes in vitro is reflected by the genome-wide analysis of chromatin structure in vivo. In $P f$, large genomic regions lack positioned nucleosomes or even appear to lack histone octamers on DNA at all. Several studies have addressed the nucleosomal landscape in $P$. falciparum, using Sonication-ChIP, MNase-ChIP, MNase-Seq and other methods, such as ATAC-seq and FAIRE, to detect nucleosome-free regions [18,45,46,58,79-81]. In summary, these studies show higher nucleosome density in heterochromatin, but contradicting experimental results were obtained regarding nucleosome occupancy in genic or intergenic regions. This review focuses on describing the nucleosomal landscape. For this, we largely exclude the description of FAIRE- and ATAC-seq experiments, as these methods monitor accessible DNA regions, not nucleosomal architecture. Recent studies addressing human and Drosophila chromatin have revealed the existence of nucleosomes with different stability $[64,82]$ and, in order to assess all nucleosomes on DNA, appropriate protocols have been established. It was shown that partial MNase digestion of chromatin with still intact di- and tri-nucleosome fragments improves the overall sequencing coverage of nucleosomal DNA and avoids the loss of MNase-sensitive nucleosomes that are preferentially located at regulatory regions $[64,82]$. Taking into account these recent insights, we focus on experimental data that omit MNase digestion bias, in order to provide a clearer overview of Plasmodium falciparum chromatin structure. The only study so far using limited MNase digestion conditions was performed by Kensche and colleagues [18].

Intriguingly, the transcriptional unit of a typical gene in P. falciparum is framed by positioned nucleosomes upstream and downstream of the coding region (see Figure 2), resulting in the covering of regulatory regions and functional elements in the genome by positioned nucleosomes. A positioned +1 nucleosome can be mapped right at the TSS next to an upstream nucleosome-depleted region (NDR) of variable size and a detectable -1 nucleosome upstream of the NDR. This is a common pattern in eukaryotes, albeit the clarity and effectiveness of nucleosome positioning at these sites appear to be relaxed. The width of the NDR varies between individual $P f$ core promotors with a tendency of larger NDRs being associated with higher transcription levels. Positioned nucleosomes can also be detected at start and stop codons, as well as at splicing sites, which are relatively static throughout the life cycle. Nucleosomes positioned at start/stop codons may occur solely because of the increased GC-content of coding sequences, whereas those at exonintron boundaries might be actively positioned to allow recruitment of post-transcriptional machineries. Overall, these observations suggest that nucleosome positions somehow highlight transcriptionally relevant landmarks, but positioning is less stringent and more fuzzy when compared to other eukaryotes. The MNase-seq data also indicated the typical $10 \mathrm{bp}$ periodicity signal for AA/TT-dinucleotide driven nucleosome positioning in genic and intergenic regions, suggesting it is an additional, albeit less pronounced, feature of nucleosome positioning in Plasmodium. Kensche and colleagues suggest this much fuzzier pattern to be a global effect originating in the merging of multiple genes displaying 
different nucleosome patterns. Alternatively, the fuzziness could be a local consequence of the divergent stability and positioning properties of $P f$ nucleosomes within individual genes and thus, point to a distinct chromatin organization [49].

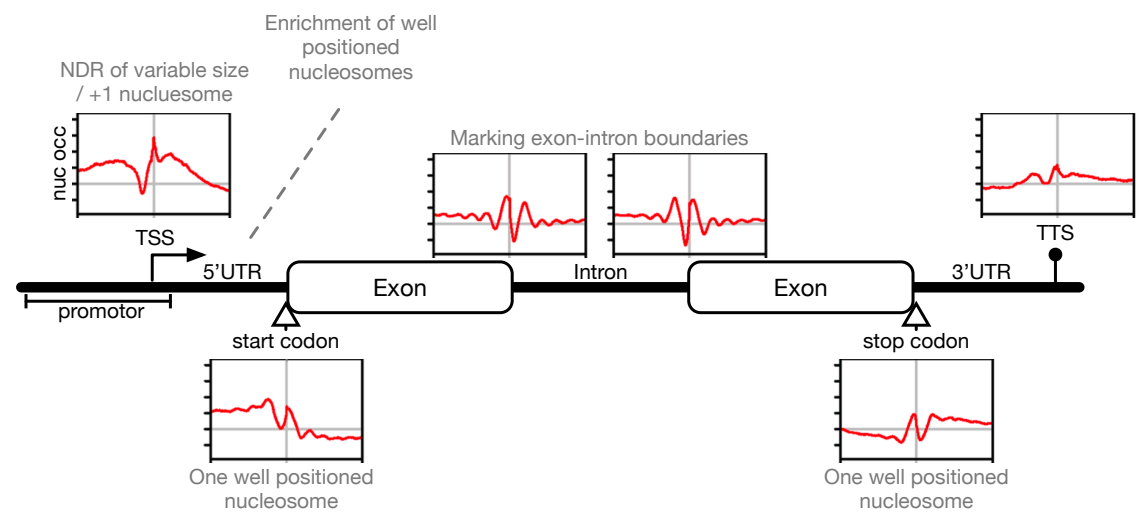

Figure 2. Schematic illustration of a typical gene with transcriptional landmark sites and corresponding plasmodial nucleosome positioning. The nucleosome profiles show the average MNase-seq occupancy normalized by gDNA aligned to the respective gene element combining eight time-points throughout the erythrocytic cycle according to [18]. Functional gene elements are designated, transcription start/stop is indicated arrow-/circle-tipped above the gene, translation start/stop codons are marked by arrows below the gene.

Comparative analysis of nucleosome-positioning dynamics at different life cycle stages shows that most nucleosomes in the transcriptional unit are static and nondynamic, indicating no gross changes of chromatin structure with variable gene expression. However, upstream promotor regions show significant changes in nucleosome occupancy levels during the life cycle, correlating with changes in gene transcription. With increasing transcriptional activity, nucleosome-depleted regions appear, which may be related to the formation of the RNA polymerase II initiation complexes. Accordingly, gene repression correlates with dynamic increases in nucleosome levels inhibiting transcription initiation $[18,58,80]$. The data suggest local changes in nucleosome occupancy around specific DNA motifs within these $5^{\prime}$ intergenic region being indicative of transcription factor binding, whereas global chromatin structure stays unaltered throughout the life cycle [18].

Studies mapping the genomic localization of nucleosomes containing the histone variants H2A.Z and H2B.Z identified them in the intergenic regions of euchromatin domains, particularly enriched at gene promotors [19,67-69]. The variant nucleosome levels do not change during the life cycle, suggesting that they permanently mark promotors and regulatory regions. The transcriptional activation of the heterochromatic var genes represents an exception to this rule, as the H2A.Z/B.Z levels at these promoters correlate with increased transcription level [68]. Moreover, the histone variant $P f \mathrm{H} 3.3$ is preferentially located at euchromatic coding and subtelomeric repetitive sequences unrelated to transcription, whereas in other eukaryotes H3.3 is incorporated at sites of active transcription [83]. Interestingly, $P f \mathrm{H} 3.3$ incorporation was also found at promotors of poised and active (but not inactive) var genes pointing to its putative contribution to epigenetic memory in var gene expression [70].

Not only the histone variant distribution, but also the occupancy and positioning of Pf nucleosomes in general do not quite follow known eukaryotic principles. The highly divergent underlying determinants-DNA and histone properties-seem to shape a very different chromatin landscape in Plasmodium falciparum, and potential novel mechanisms may have evolved to allow for the tightly regulated gene expression program in the parasite. 


\subsection{Chromatin Density and Nuclear Organization}

Progressing through the erythrocytic life cycle, major changes in nucleosome occupancy were reported, obtained via high MNase digestion and Hi-C techniques [58,79,84]: the ring stages exhibit high nucleosome occupancy, whereas a depletion of nucleosomes was observed in the trophozoite stage, potentially opening chromatin for transcription and DNA replication. In the following schizont stage, nucleosome occupancy increases again, correlating with chromatin compaction for merozoite differentiation and egress. The chromatin structure in gametocytes was found to be relatively open. These global changes in chromatin accessibility within the life cycle are specific to P. falciparum and have not been reported to a comparable extent in any other eukaryote.

Nuclear organization is proposed to be another epigenetic layer contributing to gene expression regulation using mechanisms such as rearrangement of chromosomes, locus repositioning and heterochromatic silencing [85]. Various studies have attempted to unveil the three-dimensional nuclear organization of Plasmodium falciparum using chromosome conformation capture techniques (reviewed in $[85,86]$ ). One characteristic of P. falciparum is the absence of chromosome territories supporting the presence of a relatively accessible chromatin structure. Although clustering for certain genomic domains, such as heterochromatin foci, telomeres and ribosomal DNA, could be shown, no pronounced chromosome condensation comparable to other eukaryotes was observed [87].

\section{Epigenetic Regulation of Transcriptional Activity}

As described in the previous sections, gene transcription is impacted by a combination of epigenetic features shaping the chromatin landscape: the main determinants are the variations of nucleosome occupancy and nucleosome positioning at specific DNA elements and histone variants, in addition to the dynamic histone PTMs as well as higher-order chromatin structures. Furthermore, long noncoding RNAs [88,89] have been suggested to contribute to gene regulation by serving as modular scaffolds and targeting modules that recruit chromatin-modifying enzymes to specific loci $[90,91]$. Finally, the driving force is the accessibility of promotors and enhancers within chromatin-implemented by correct nucleosome positioning-for transcription-factor binding and the initiation of complex formation [92].

Genome-wide MNase-seq [18] and ATAC-seq data [46] confirm this principle in P. falciparum: Kensche and colleagues identified 4821 dynamic nucleosomes with 80 percent being located in euchromatic intergenic regions, mainly at promotors. The dynamics of these nucleosomes clearly correlate with temporal transcriptional activity of the downstream gene. Toenhake and colleagues identified 4035 accessible regions, whereof 90 percent are located in intergenic regions. The majority was found to be associated with one or more putative promotors and to correlate in accessibility score with abundance of the downstream gene product.

For some genes with high transcriptional variation, the epigenetic mechanisms were investigated in more detail (reviewed in [85]): the group of invasion genes was found to exist in an activated state caused by an interplay of the transcription factor AP2-I with the bromodomain-binding protein BDP1 binding to H3K9ac [93]. A repressed state in contrast - extensively studied on the example of var genes-is maintained by heterochromatin protein HP1, histone deacetylase HDA2 and the histone lysine methyltransferase SET2 and marked by H3K9me3 rendering these genes heterochromatic [94-97]. Furthermore, a chromatin-remodeling enzyme [PF3D7_0624600] and sirtuin proteins influence chromatin condensation [98,99], and the incorporation of noncoding RNAs complement the var gene-switching mechanism by silencing the gene locus via its sense-activating via its antisense-lncRNA $[90,100]$. Sexual commitment is known to be regulated by the epigenetic cascade starting with Ap2-G expression being repressed by HP1, which is evicted upon gametocyte development 1 (GDV1) association to heterochromatin, and GDV1 itself is controlled by the $g d v 1$ antisense RNA $[35,97,101,102]$. 
These examples illustrate the multilayered nature of epigenetic regulation, but concomitant nucleosome occupancy and positioning were hardly taken into consideration. However, in all of the described processes, nucleosome occupancy determines any interactions with the underlying DNA locus and certainly contributes to the unveiled regulatory mechanism. The importance of nucleosome occupancy was highlighted in a machinelearning model, wherein the relevance of individual epigenetic features in relation to the entirety of transcription regulation was assessed [77]: a collection of genomic and epigenomic data sets including information about transcription factor binding motifs, patterns of covalent histone modifications, nucleosome occupancy, GC content and global 3D genome architecture were analyzed for their prevalence in high-/low-expression genes. This kind of comparative analysis emphasizes the relevance of histone modifications, nucleosome occupancy and 3D chromatin architecture and suggests transcription-factor binding to be less important for transcription regulation.

\section{Chromatin Remodeling Enzymes}

All DNA-dependent processes require dynamic changes in chromatin organization to exert their DNA specific activities. For this, eukaryotic cells have developed numerous enzymes that change the organization of DNA packaging [103]. Chromatin-remodeling enzymes alter chromatin structure by moving nucleosomes, while chromatin modifiers leave their chemical marks on chromatin to change the physicochemical properties of the chromatin fiber or to target protein/RNA complexes to specific genomic loci. The high variability of global and local chromatin packaging states and the numerous chromatin modifications associated with different functional processes, demonstrate the superordinate role of chromatin proteins in eukaryotic cells. On that account, it is important to study this emerging field in Plasmodium falciparum, as the fundamental differences between chromatin proteins in humans and Plasmodium will provide new insights into the evolution and mechanisms of chromatin dynamics and may reveal new therapeutic options.

In a comparative genomics study, the evolution of transcription factors, chromatinmodifying and -remodeling enzymes in parasitic protists was reconstructed [104]: Intriguingly, chromatin proteins evolved over millions of years in independent eukaryotic lineages through the proliferation of paralogous families and acquisition of novel domain architectures, leading to an enormous variety and to highly diverse sets of enzymes. Some chromatin-modifying enzymes have been identified in Plasmodium falciparum (detailed review in [105]). In this review we will focus on the evolution and mechanisms of chromatin-remodeling enzymes.

Remodeling enzymes and the large multiprotein complexes they form exert a direct ATP-dependent effect on nucleosomes. The enzymes alter histone-DNA interactions, resulting in the eviction, exchange and assembly of individual histones or histone octamers, changing the structure and stability of nucleosomes or the movement of histone octamers on DNA to reposition nucleosomes (reviewed in $[43,106]$ ). In order to disrupt the very stable interaction between histones and DNA, these enzymes couple their activity to ATP hydrolysis. A highly conserved ATPase module is conserved within all chromatinremodeling enzymes, which is split into a Snf2_N and a helicase C domain, separated by a P-loop. The enzymes generally exhibit several additional protein domains, determining their specificity in substrate recognition and interaction with other proteins or RNA to form a variety of protein complexes [107].

The essential molecular function of this enzyme family is the movement of nucleosomes in order to provide accessibility to certain DNA regions. However, the exact regulatory mechanisms of this process-with respect to which nucleosomes are recognized to be moved and what is the target position - have not been completely uncovered. There is some evidence of "high affinity" and "low affinity" nucleosomes representing a putative mechanism or at least one aspect of defining reaction educts and products [108]. Therefore, multiple factors, such as the recognition of DNA sequences and structures, nucleosome composition and histone PTMs, play a crucial role. The specificity of remodeling 
machines depends furthermore on the central motor protein as well as the composition of all the associated complex subunits dramatically changing the responsiveness to various substrates and recruiting mechanisms. $[43,106]$. In human and mouse cells, it was estimated that over 1000 different chromatin-remodeling complexes with distinct functions may exist. Their cell-type-specific combination and dosage probably determines the cell-type-specific chromatin architecture, the gene-expression network and the responsiveness to specific signaling pathways in the cell $[43,106,108-110]$. To name an example, Snf2H—one of the 53 remodeling enzymes in humans-was biochemically purified in 18 different multiprotein complexes emphasizing the complexity of the "remodeling code" [111].

The functionally different subfamilies of SWI/SNF ATPases are grouped by the homology of the helicase region according to Flaus et al. (indicated by coloring in Figure 3) [112]: Starting with the Snf2-like group, the ISWI subfamily is mainly responsible for nucleosome repositioning, playing a role in nucleosome stabilization and higher-order structure $[113,114]$. In contrast, Snf2 enzymes have a more disruptive effect on nucleosomes, and Lsh proteins are associated with transcription silencing, cooperating with methyltransferases [115-117]. Chd proteins, comprising the Chd1, Mi-2 and Chd7 subfamilies, possess specific nucleosome remodeling activities and are characterized by their additional chromodomain. They are involved in processes like chromatin assembly nucleosome spacing $[118,119]$ or function as regulators of gene expression in functionally distinct complexes $[120,121]$. The principal functions of the Swr1-like group-identifiable by the divided helicase domain and HSA domain-include histone eviction and the exchange of variants [122]. Rad54-like proteins seem to change DNA topology and alter nucleosomal accessibility [123], while Rad5/16 is involved in DNA repair pathways using its characteristic RING finger domain [124]. The SSO1652like family does not directly alter nucleosome structure but is proposed to interact with transcription factors and is recruited to DNA lesions [115-117,125]. Last, a function for the distant group has not yet been determined. This selective overview indicates the functional diversity between the subfamilies of enzymes that depend on the highly conserved ATPase domain in combination with the additional complex subunits. The interplay of all these complexes in the cell organizes the nucleosomal landscape in a complex manner and, with this, the accessibility of regulatory DNA elements. Regulation of nucleosome positioning, keeping nucleosomes over regulatory sites-OFF state- or moving them next to the binding sites of regulatory factor- $\mathrm{ON}$ state configuration-likely determines local gene activity states. This mechanism can be paraphrased as "barcoding" the nucleosome landscape and highlights the essential role of remodeling enzymes in regulation and cellular differentiation [126].

Hidden Markov model (HMM) profile studies in P. falciparum revealed 10 genes encoding putative SWI2/SNF2 ATPases [12] and sharing similarities within the several subgroups, but with particularly low conservation when compared to other eukaryotes. According to evolutionary studies of Iyer and colleagues, remodeling enzymes had their origins in the bacteriophage replication system, and thereafter, a set of six enzymes with conserved domain architecture was suggested to be present in the last eukaryotic common ancestor (LECA) (Figure 3, left panel) [104]. During evolution, prior to the origin of kinetoplasts and then chromalveolates, new families of remodeling enzymes evolved with precursors of the Rad5/16 group, distant group, ALC1, Lsh and Etl1. Early on, the apicomplexan line evolved ten chromatin remodelers, whereof eight proteins could be allocated in the evolutionary model of Iyer and colleagues, based on homology search and domain architecture (Figure 3, mid panel). Higher eukaryotes developed a huge variety of SWI2/SNF2 ATPases starting from a few ancient types, e.g. leading to more than 50 in human cells (Figure 3, right panel) [112]. In comparison, P. falciparum possesses a limited set of 10 enzymes, only one per family, and therefore lacks the typical redundancy seen in higher eukaryotes, suggesting that these enzymes perform essential tasks in the cell. This fundamental difference in numbers between human cells and P. falciparum is accompanied in highly divergent domain architectures. Some domains such as $\mathrm{PhD}$, Chromo and SANT domains, could be identified at very low stringency in sequence comparison but with no indication of their specific functions in $P f$. 

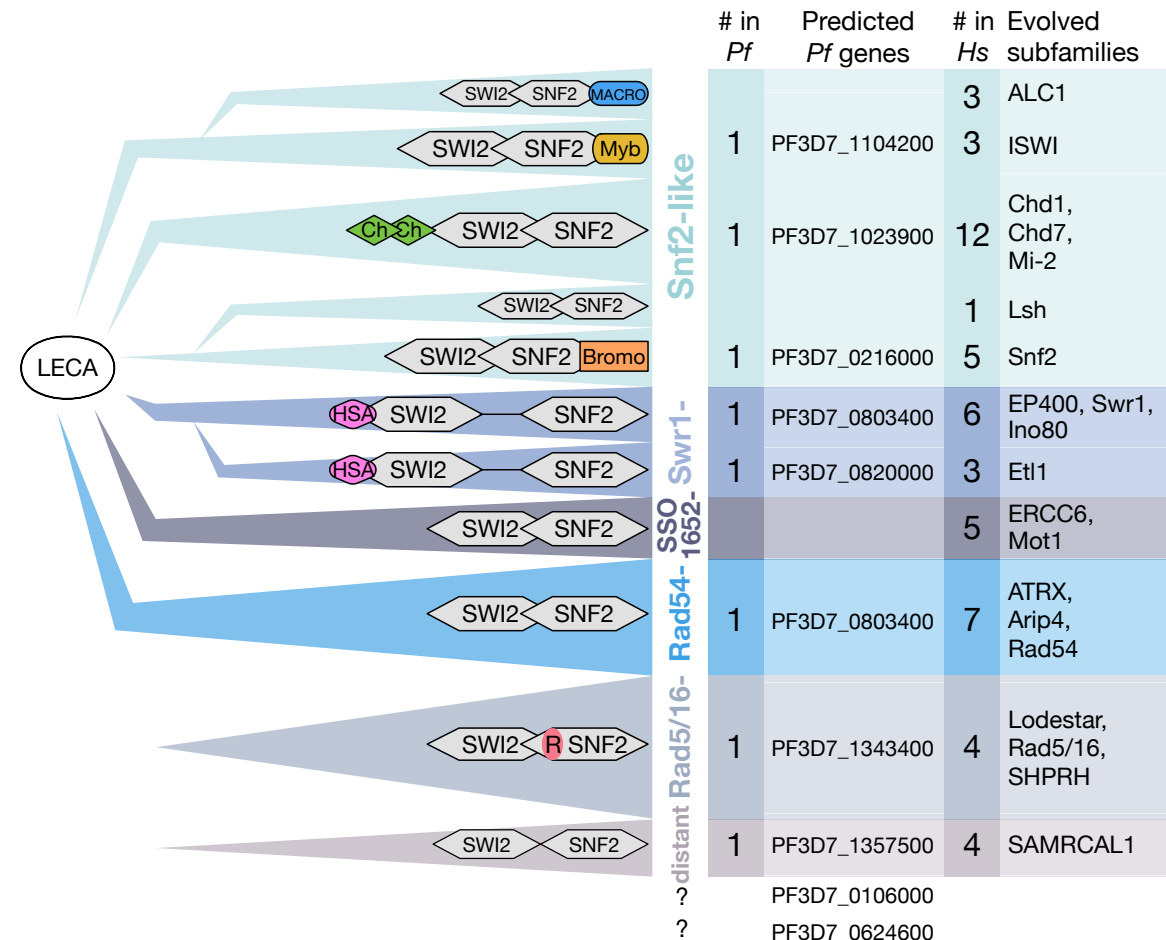

Figure 3. Evolutionary and phylogenetic development of SW2I/SNF2 ATPases. The evolution of SWI2/SNF2 starting from last eukaryotic common ancestor (LECA), according to [104], with triangles grouping together multiple subfamilies and their conserved domain architecture illustrated (left panel). Grouping of subfamilies and their names, according to [112], are indicated by coloring. SWI2-/SNF2-encoding genes in P. falciparum-wherever possible-were allocated to the categorization. Numbers of prevalent proteins for P. falciparum and H. sapiens, as well as names of further evolved subfamilies, are provided. Domain names: $\mathrm{Ch}=\mathrm{Chromo}, \mathrm{R}=\mathrm{RING}, \mathrm{HAS}=$ helicase/SANT-associated.

The individual remodeling enzymes in P. falciparum, and Apicomplexa in general, remain poorly characterized so far. In a pioneering study, Ji and Arnot identified and classified the first SWI2/SNF2 enzyme (Snf2L) with approximately 60\% sequence homology to the ATPase domain of the yeast ISWI remodeler [127]. Since then, only a few studies addressed apicomplexan remodelers [98,128]. A genome-wide mutagenesis screen proposed one of the plasmodial remodelers to be essential and another two as putatively essential in asexual blood stages [9]. The authors suggest that the rest are not crucial for parasite fitness, not precluding the possibility of significant roles in chromatin organization.

In general, perhaps with the exception of Chd1, all chromatin-remodeling enzymes are part of large multiprotein complexes with characteristic binding partners that link the enzymes to chromatin modifiers, chromatin and DNA binding motifs and alter the functionality of the complexes [109]. Interestingly, homology searches did not retrieve a single homologue of these proteins in P. falciparum. This astonishing lack of known interactors in combination with the reduced number and high divergence in sequence indicates that the chromatin-remodeling system in Plasmodium differs from known mechanisms in higher eukaryotes.

\section{Potential Regulatory Network}

As elaborated in the previous sections, Plasmodium falciparum chromatin is unusual in many respects, from the reduced number of transcription factors to high nucleosome dynamics and the divergent chromatin-remodeling enzymes/complexes. Therefore, we hypothesize that $P$. falciparum possesses a highly regulated but distinct chromatin system 
when compared to other eukaryotes. Here we address how these differences may affect the regulatory network and the transcriptional program throughout the parasite life cycle (Figure 4).

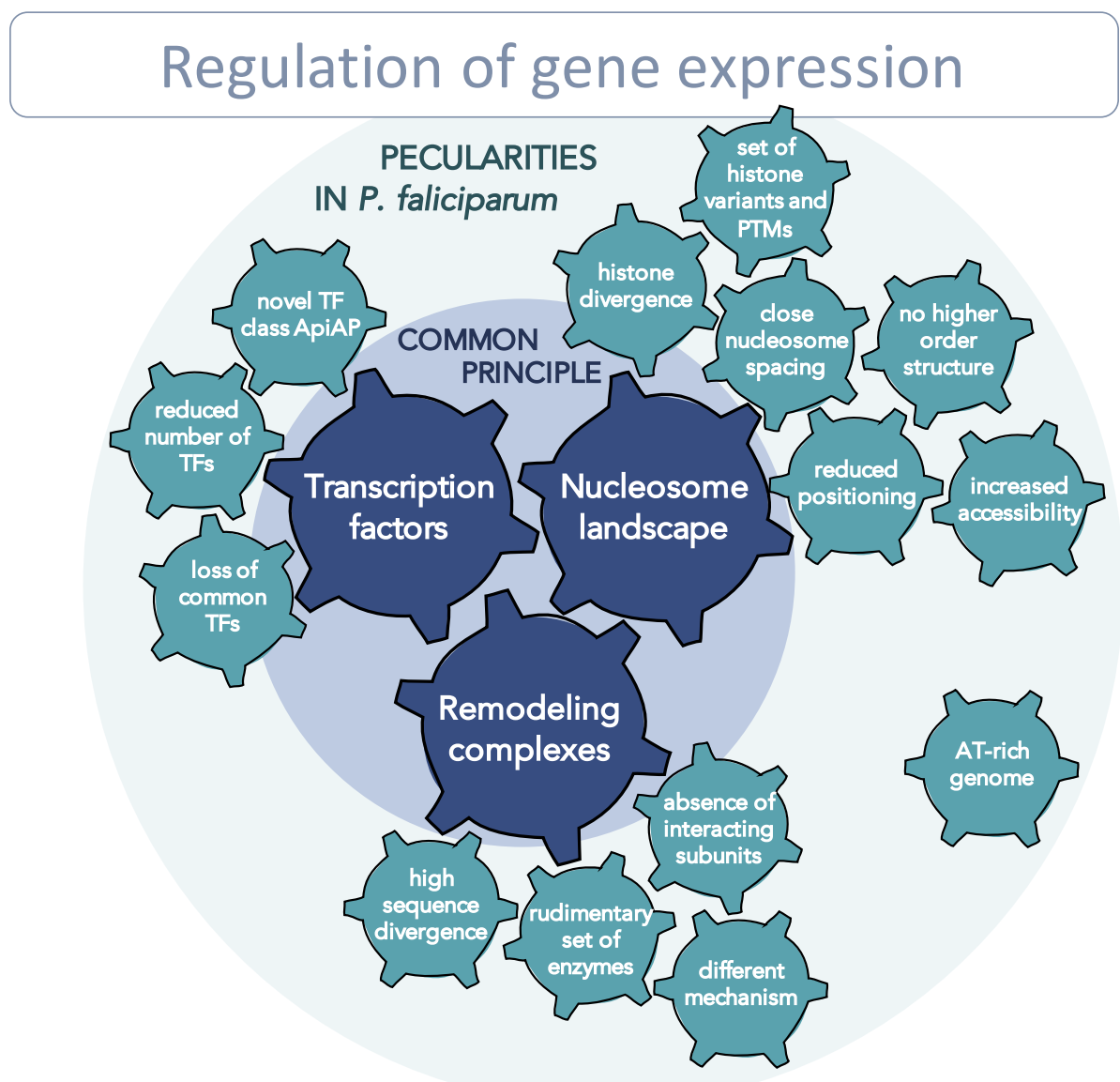

Figure 4. Schematic representation of the regulatory network of gene expression, with peculiar features in P. falciparum that affect the common principles.

One crucial parameter for transcription regulation is the nucleosome landscape, which was investigated in several studies within the last few years. Conclusively, these studies point out a highly dynamic chromatin structure and atypical nucleosome features in $P$. falciparum $[18,49,79]$. The overall $P f$ chromatin was found to have a more open structure; the spacing of nucleosomes is surprisingly short; it is not organized in defined higher-order structures, and the nucleosomes themselves show reduced stability and lost capacity for sequence-dependent positioning (see Sections 3.1 and 3.4). It is not known what exactly causes these altered nucleosome properties, but the extraordinary AT-rich genome and the extraordinarily high sequence divergence of $P f$ histones might interoperate to form this particular chromatin structure.

However, the applied methodology of chromatin analysis in Plasmodium parasites and the interpretation of the results is still a matter of discussion. On one hand, the AT-rich nature of the DNA is known to bias sequencing techniques [129]. On the other hand, the parasite rapidly moving through its highly different life cycle stages also blur the clarity of the observations. The fuzziness of $P f$ nucleosomal landscapes might be the consequence of highly unstable nucleosomes but could also represent the dynamic nature of chromatin in this organism. A strictly regulated but rapidly changing nucleosomal landscape is hard to capture precisely with the available techniques so far.

The second pillar of transcriptional regulation is formed by transcription factors and their interaction with cis-acting regulatory elements. The set of TFs that exist in $P$. falciparum was identified and characterized to some extent within the last few years, and 
the binding motifs and binding sites for many of them were identified. For the binding of certain transcription factors, such as Api2-G or Api2-O, defined downstream effects on the transcriptome were observed [32]. Since only a reduced number of TFs, primarily members of the ApiAP2 family were found, their relevance in gene-expression control is questionable. In any case, the mechanism of trans-regulatory factors is closely linked to the nucleosome landscape, since the accessibility of binding regions is an essential prerequisite for factor binding $[92,130]$. Therefore, promotor regions need to be nucleosome-depleted to enable TF binding. A detailed analysis of nucleosome positioning relative to TF binding regions would give us important information about the hierarchy of coaction between those two levels of regulation. Is the DNA region around the binding motif permanently nucleosome-depleted and thus accessible for TF-binding? If not, which mechanisms are responsible for uncovering these regions? Are some of the transcription factors pioneer factors that are capable of recognizing nucleosome-occupied motifs and subsequently recruiting chromatin-remodeling activities? These questions about specificity, recruitment and the order of events are important open issues in the field.

We propose that, for transcription regulation in Plasmodium falciparum, the chromatinremodeling machinery is a third crucial determinant, strongly interlinked with the binding of transcription factors to DNA. As DNA properties explain the nucleosomal landscape only in part, active movement and positioning by remodelers has a high impact on nucleosome positioning and thus, on gene expression regulation $[43,106,131]$ : remodeling complexes are recruited to target genes by transcription factors, RNA polymerases and elongation factors to promote or block transcription initiation and elongation by rearranging nucleosomes. They are the engines that both block (repression) or enable (activation) access to a gene through movement, positioning and the eviction/insertion of nucleosomes, depending on the specific type of remodeling enzyme at this locus. Remodeling complexes may barcode the genome in each stage of the life cycle, meaning that they establish a nucleosome-positioning landscape that allows the binding of certain factors and, conversely, restricts accessibility for other factors. Current investigations attempt to decipher this "remodeling code" and address the questions of how genomic loci are specifically recognized and how these enzymes are regulated. Which features determine the affinity to individual nucleosomes, serving as parameter for locus-specific nucleosome positioning? Another question is what is within the scope of function of the motor protein itself and what features are mediated by complex subunits? Looking at one level above, the regulation of remodeling enzymes themselves need to be investigated; it is presumed to occur in three different ways: control takes place (a) via recruiting to the correct target site by sensing the histone code or other factors [43]; (b) via adjustment of enzyme activity, e.g., by post-transcriptional protein-modification or ncRNAs [91]; or (c) by changing associated subunits and thus, conferring different activities to the complex (reviewed in [106]).

How remodeling enzymes pave the way for transcription-factor and polymerase binding and how they are regulated is completely unexplored in P. falciparum. Based on the reduced number of identified $P f$ enzymes with high sequence divergence and the absence of any known interacting subunits, as there are in higher eukaryotes, we expect functional divergence. We propose that $P f$ remodeling complexes-closely linked with the nucleosome landscape and transcription-factor binding-build a complex regulatory network exhibiting major differences in comparison to other eukaryotes. The decryption of this system is indispensable to understanding the mechanism of transcription regulation in the parasite and will provide new insights and novel approaches for fighting malaria.

Author Contributions: Writing - original draft preparation, M.T.W. and G.L.; writing-review and editing, M.T.W., S.D., M.M. and G.L.; funding acquisition, G.L. All authors have read and agreed to the published version of the manuscript.

Funding: This research was funded by Deutsche Forschungsgemeinschaft (SFB960).

Conflicts of Interest: The authors declare no conflict of interest. 


\section{References}

1. World Health Organization. World Malaria Report 2020: 20 Years of Global Progress and Challenges; WHO: Geneva, Switzerland, 2020.

2. Haldar, K.; Bhattacharjee, S.; Safeukui, I. Drug resistance in Plasmodium. Nat. Rev. Genet. 2018, 16, 156-170. [CrossRef] [PubMed]

3. Douzery, E.J.P.; Snell, E.A.; Bapteste, E.; Delsuc, F.; Philippe, H. The timing of eukaryotic evolution: Does a relaxed molecular clock reconcile proteins and fossils? Proc. Natl. Acad. Sci. USA 2004, 101, 15386-15391. [CrossRef] [PubMed]

4. Sinka, M.E.; Bangs, M.J.; Manguin, S.; Rubio-Palis, Y.; Chareonviriyaphap, T.; Coetzee, M.; Mbogo, C.M.; Hemingway, J.; Patil, A.P.; Temperley, W.H.; et al. A global map of dominant malaria vectors. Parasites Vectors 2012, 5, 69. [CrossRef]

5. Reece, J.B.; Campbell, N.A. Campbell Biology; Benjamin Cummings/Pearson: Boston, MA, USA, 2011.

6. Gardner, M.J.; Hall, N.; Fung, E.; White, O.; Berriman, M.; Hyman, R.W.; Carlton, J.M.; Pain, A.; Nelson, K.E.; Bowman, S.; et al. Genome sequence of the human malaria parasite Plasmodium falciparum. Nat. Cell Biol. 2002, 419, 498-511. [CrossRef] [PubMed]

7. Böhme, U.; Otto, T.D.; Sanders, M.; Newbold, C.I.; Berriman, M. Progression of the canonical reference malaria parasite genome from 2002-2019. Wellcome Open Res. 2019, 4, 58. [CrossRef]

8. Su, X.-Z.; Lane, K.D.; Xia, L.; Sá, J.M.; Wellems, T.E. PlasmodiumGenomics and Genetics: New Insights into Malaria Pathogenesis, Drug Resistance, Epidemiology, and Evolution. Clin. Microbiol. Rev. 2019, 32. [CrossRef] [PubMed]

9. Zhang, M.; Wang, C.; Otto, T.D.; Oberstaller, J.; Liao, X.; Adapa, S.R.; Udenze, K.; Bronner, I.F.; Casandra, D.; Mayho, M.; et al. Uncovering the essential genes of the human malaria parasite Plasmodium falciparum by saturation mutagenesis. Science 2018, 360 , eaap7847. [CrossRef]

10. Le Roch, K.G.; Zhou, Y.; Blair, P.L.; Grainger, M.; Moch, J.K.; Haynes, J.D.; De La Vega, P.; Holder, A.A.; Batalov, S.; Carucci, D.J.; et al. Discovery of Gene Function by Expression Profiling of the Malaria Parasite Life Cycle. Science 2003, 301, 1503-1508. [CrossRef]

11. Francis, W.R.; Wörheide, G. Similar Ratios of Introns to Intergenic Sequence across Animal Genomes. Genome Biol. Evol. 2017, 9, 1582-1598. [CrossRef]

12. Horrocks, P.; Wong, E.; Russell, K.; Emes, R.D. Control of gene expression in Plasmodium falciparum-Ten years on. Mol. Biochem. Parasitol. 2009, 164, 9-25. [CrossRef]

13. Toenhake, C.G.; Bártfai, R. What functional genomics has taught us about transcriptional regulation in malaria parasites. Brief. Funct. Genom. 2019, 18, 290-301. [CrossRef] [PubMed]

14. Watanabe, J.; Sasaki, M.; Suzuki, Y.; Sugano, S. Analysis of transcriptomes of human malaria parasite Plasmodium falci-parum using full-length enriched library: Identification of novel genes and diverse transcription start sites of messenger RNAs. Gene 2002, 291, 105-113. [CrossRef]

15. Pesole, G. UTRdb and UTRsite: Specialized databases of sequences and functional elements of 5' and 3' untranslated regions of eukaryotic mRNAs. Update 2002. Nucleic Acids Res. 2002, 30, 335-340. [CrossRef]

16. Adjalley, S.H.; Chabbert, C.D.; Klaus, B.; Pelechano, V.; Steinmetz, L.M. Landscape and Dynamics of Transcription Initiation in the Malaria Parasite Plasmodium falciparum. Cell Rep. 2016, 14, 2463-2475. [CrossRef] [PubMed]

17. Horrocks, P.; Lanzer, M. Differences in nucleosome organization over episomally located plasmids coincides with aber-rant promoter activity in P. falciparum. Parasitol. Int. 1999, 48, 55-61. [CrossRef]

18. Kensche, P.R.; Hoeijmakers, W.A.M.; Toenhake, C.G.; Bras, M.; Chappell, L.; Berriman, M.; Bártfai, R. The nucleosome landscape of Plasmodium falciparum reveals chromatin architecture and dynamics of regulatory sequences. Nucleic Acids Res. 2016, 44, 2110-2124. [CrossRef] [PubMed]

19. Bártfai, R.; Hoeijmakers, W.A.M.; Salcedo-Amaya, A.M.; Smits, A.H.; Janssen-Megens, E.; Kaan, A.; Treeck, M.; Gilberger, T.-W.; Françoijs, K.-J.; Stunnenberg, H.G. H2A.Z Demarcates Intergenic Regions of the Plasmodium falciparum Epigenome That Are Dynamically Marked by H3K9ac and H3K4me3. PLoS Pathog. 2010, 6, e1001223. [CrossRef] [PubMed]

20. Iengar, P.; Joshi, N. Identification of putative regulatory motifs in the upstream regions of co-expressed functional groups of genes in Plasmodium falciparum. BMC Genom. 2009, 10, 18. [CrossRef]

21. Wu, J.; Sieglaff, D.H.; Gervin, J.; Xie, X.S. Discovering regulatory motifs in the Plasmodium genome using comparative genomics. Bioinformatics 2008, 24, 1843-1849. [CrossRef]

22. Young, J.A.; Johnson, J.R.; Benner, C.; Yan, S.F.; Chen, K.; Le Roch, K.G.; Zhou, Y.; Winzeler, E.A. In silico discovery of transcription regulatory elements in Plasmodium falciparum. BMC Genom. 2008, 9, 1-21. [CrossRef]

23. Ubhe, S.; Rawat, M.; Verma, S.; Anamika, K.; Karmodiya, K. Genome-wide identification of novel intergenic enhancer-like elements: Implications in the regulation of transcription in Plasmodium falciparum. BMC Genom. 2017, 18, 1-16. [CrossRef]

24. Wang, C.; Gibbons, J.; Adapa, S.R.; Oberstaller, J.; Liao, X.; Zhang, M.; Adams, J.H.; Jiang, R.H. The human malaria parasite genome is configured into thousands of coexpressed linear regulatory units. J. Genet. Genom. 2020, 47, 513-521. [CrossRef] [PubMed]

25. Bischoff, E.; Vaquero, C. In silico and biological survey of transcription-associated proteins implicated in the transcriptional machinery during the erythrocytic development of Plasmodium falciparum. BMC Genom. 2010, 11, 34. [CrossRef] [PubMed]

26. Hahn, S.; Young, E.T. Transcriptional Regulation in Saccharomyces cerevisiae: Transcription Factor Regulation and Function, Mechanisms of Initiation, and Roles of Activators and Coactivators. Genetics 2011, 189, 705-736. [CrossRef] [PubMed]

27. Zhang, H.-M.; Chen, H.; Liu, W.; Liu, H.; Gong, J.; Wang, H.; Guo, A.-Y. AnimalTFDB: A comprehensive animal transcription factor database. Nucleic Acids Res. 2011, 40, D144-D149. [CrossRef] [PubMed] 
28. Lambert, S.A.; Jolma, A.; Campitelli, L.F.; Das, P.K.; Yin, Y.; Albu, M.; Chen, X.; Taipale, J.; Hughes, T.R.; Weirauch, M.T. The Human Transcription Factors. Cell 2018, 172, 650-665. [CrossRef] [PubMed]

29. Balaji, S. Discovery of the principal specific transcription factors of Apicomplexa and their implication for the evolution of the AP2-integrase DNA binding domains. Nucleic Acids Res. 2005, 33, 3994-4006. [CrossRef] [PubMed]

30. Coulson, R.M.; Hall, N.; Ouzounis, C.A. Comparative Genomics of Transcriptional Control in the Human Malaria Parasite Plasmodium falciparum. Genome Res. 2004, 14, 1548-1554. [CrossRef]

31. Campbell, T.L.; De Silva, E.K.; Olszewski, K.L.; Elemento, O.; Llinás, M. Identification and Genome-Wide Prediction of DNA Binding Specificities for the ApiAP2 Family of Regulators from the Malaria Parasite. PLoS Pathog. 2010, 6, e1001165. [CrossRef]

32. Jeninga, M.D.; Quinn, J.E.; Petter, M. ApiAP2 Transcription Factors in Apicomplexan Parasites. Pathogens 2019, 8, 47. [CrossRef]

33. Modrzynska, K.; Pfander, C.; Chappell, L.; Yu, L.; Suarez, C.; Dundas, K.; Gomes, A.R.; Goulding, D.; Rayner, J.C.; Choudhary, J.; et al. A Knockout Screen of ApiAP2 Genes Reveals Networks of Interacting Transcriptional Regulators Controlling the Plasmodium Life Cycle. Cell Host Microbe 2017, 21, 11-22. [CrossRef]

34. Iwanaga, S.; Kaneko, I.; Kato, T.; Yuda, M. Identification of an AP2-family Protein That Is Critical for Malaria Liver Stage Development. PLoS ONE 2012, 7, e47557. [CrossRef]

35. Kafsack, B.F.C.; Rovira-Graells, N.; Clark, T.G.; Bancells, C.; Crowley, V.M.; Campino, S.G.; Williams, A.E.; Drought, L.G.; Kwiatkowski, D.P.; Baker, D.A.; et al. A transcriptional switch underlies commitment to sexual development in malaria parasites. Nat. Cell Biol. 2014, 507, 248-252. [CrossRef] [PubMed]

36. Santos, J.M.; Josling, G.; Ross, P.; Joshi, P.; Orchard, L.; Campbell, T.; Schieler, A.; Cristea, I.M.; Llinás, M. Red Blood Cell Invasion by the Malaria Parasite Is Coordinated by the PfAP2-I Transcription Factor. Cell Host Microbe 2017, 21, 731-741.e10. [CrossRef] [PubMed]

37. Yuda, M.; Iwanaga, S.; Shigenobu, S.; Mair, G.R.; Janse, C.J.; Waters, A.P.; Kato, T.; Kaneko, I. Identification of a transcription factor in the mosquito-invasive stage of malaria parasites. Mol. Microbiol. 2009, 71, 1402-1414. [CrossRef]

38. Yuda, M.; Iwanaga, S.; Shigenobu, S.; Kato, T.; Kaneko, I. Transcription factor AP2-Sp and its target genes in malarial sporozoites. Mol. Microbiol. 2010, 75, 854-863. [CrossRef] [PubMed]

39. Russell, K.; Cheng, C.-H.; Bizzaro, J.W.; Ponts, N.; Emes, R.D.; Le Roch, K.G.; Marx, K.A.; Horrocks, P. Homopolymer tract organization in the human malarial parasite Plasmodium falciparum and related Apicomplexan parasites. BMC Genom. 2014, 15, 1-17. [CrossRef]

40. Van Noort, V.; Huynen, M. Combinatorial gene regulation in Plasmodium falciparum. Trends Genet. 2006, 22, 73-78. [CrossRef]

41. Levo, M.; Segal, E. In pursuit of design principles of regulatory sequences. Nat. Rev. Genet. 2014, 15, 453-468. [CrossRef]

42. Cobbold, S.A.; Santos, J.M.; Ochoa, A.; Perlman, D.H.; Llinas, M. Proteome-wide analysis reveals widespread lysine acetylation of major protein complexes in the malaria parasite. Sci. Rep. 2016, 6, 19722. [CrossRef]

43. Becker, P.B.; Workman, J.L. Nucleosome Remodeling and Epigenetics. Cold Spring Harb. Perspect. Biol. 2013, 5, a017905. [CrossRef]

44. Sales-Gil, R.; Vagnarelli, P. How HP1 Post-Translational Modifications Regulate Heterochromatin Formation and Maintenance Cells 2020, 9, 1460. [CrossRef] [PubMed]

45. Ruiz, J.L.; Tena, J.J.; Bancells, C.; Cortés, A.; Gómez-Skarmeta, J.L.; Gómez-Díaz, E. Characterization of the accessible genome in the human malaria parasite Plasmodium falciparum. Nucleic Acids Res. 2018, 46, 9414-9431. [CrossRef] [PubMed]

46. Toenhake, C.G.; Fraschka, S.A.-K.; Vijayabaskar, M.S.; Westhead, D.R.; van Heeringen, S.J.; Bártfai, R. Chromatin AccessibilityBased Characterization of the Gene Regulatory Network Underlying Plasmodium falciparum Blood-Stage Development. Cell Host Microbe 2018, 23, 557-569.e9. [CrossRef] [PubMed]

47. Baxevanis, A. Histone Sequence Database: New histone fold family members. Nucleic Acids Res. 1998, 26, 372-375. [CrossRef] [PubMed]

48. Marinov, G.K.; Lynch, M. Conservation and divergence of the histone code in nucleomorphs. Biol. Direct 2016, 11, 18. [CrossRef]

49. Silberhorn, E.; Schwartz, U.; Löffler, P.; Schmitz, S.; Symelka, A.; De Koning-Ward, T.; Merkl, R.; Längst, G. Plasmodium falciparum Nucleosomes Exhibit Reduced Stability and Lost Sequence Dependent Nucleosome Positioning. PLoS Pathog. 2016, 12, e1006080. [CrossRef]

50. Hagerman, P.J. Flexibility of DNA. Annu. Rev. Biophys. Biophys. Chem. 1988, 17, 265-286. [CrossRef]

51. Richmond, T.J.; Davey, C.A. The structure of DNA in the nucleosome core. Nat. Cell Biol. 2003, 423, 145-150. [CrossRef]

52. Widom, J. Role of DNA sequence in nucleosome stability and dynamics. Q. Rev. Biophys. 2001, 34, 269-324. [CrossRef]

53. Linzweiler, W.; Hörz, W. Reconstitution experiments show that sequence-specific histone-DNA interactions are the basis for nucleosome phasing on mouse satellite DNA. Cell 1985, 42, 281-290. [CrossRef]

54. Segal, E.; Fondufe-Mittendorf, Y.; Chen, L.; Thåström, A.; Field, Y.; Moore, I.K.; Wang, J.-P.Z.; Widom, J. A genomic code for nucleosome positioning. Nat. Cell Biol. 2006, 442, 772-778. [CrossRef] [PubMed]

55. Mengeritsky, G.; Trifonov, E.N. Nucleotide sequence-directed mapping of the nucleosomes. Nucleic Acids Res. 1983, 11, 3833-3851. [CrossRef] [PubMed]

56. Tillo, D.; Hughes, T.R. G+C content dominates intrinsic nucleosome occupancy. BMC Bioinform. 2009, 10, 442. [CrossRef] [PubMed]

57. Cui, F.; Zhurkin, V.B. Structure-based Analysis of DNA Sequence Patterns Guiding Nucleosome Positioningin vitro. J. Biomol. Struct. Dyn. 2010, 27, 821-841. [CrossRef] [PubMed] 
58. Bunnik, E.M.; Polishko, A.; Prudhomme, J.; Ponts, N.; Gill, S.S.; Lonardi, S.; Le Roch, K.G. DNA-encoded nucleosome occupancy is associated with transcription levels in the human malaria parasite Plasmodium falciparum. BMC Genom. 2014, 15, 1-15. [CrossRef]

59. Lieleg, C.; Krietenstein, N.; Walker, M.; Korber, P. Nucleosome positioning in yeasts: Methods, maps, and mechanisms. Chromosoma 2015, 124, 131-151. [CrossRef]

60. Lanzer, M.; Wertheimer, S.P.; De Bruin, D.; Ravetch, J.V. Chromatin structure determines the sites of chromosome breakages in Plasmodium falciparum. Nucleic Acids Res. 1994, 22, 3099-3103. [CrossRef]

61. Woodcock, C.L.; Ghosh, R.P. Chromatin Higher-order Structure and Dynamics. Cold Spring Harb. Perspect. Biol. 2010,2 , a000596. [CrossRef]

62. Correll, S.J.; Schubert, M.H.; Grigoryev, S.A. Short nucleosome repeats impose rotational modulations on chromatin fibre folding. EMBO J. 2012, 31, 2416-2426. [CrossRef]

63. Perišić, O.; Collepardo-Guevara, R.; Schlick, T. Modeling Studies of Chromatin Fiber Structure as a Function of DNA Linker Length. J. Mol. Biol. 2010, 403, 777-802. [CrossRef] [PubMed]

64. Schwartz, U.; Németh, A.; Diermeier, S.; Exler, J.H.; Hansch, S.; Maldonado, R.; Heizinger, L.; Merkl, R.; Längst, G. Characterizing the nuclease accessibility of DNA in human cells to map higher order structures of chromatin. Nucleic Acids Res. 2019, 47, 1239-1254. [CrossRef] [PubMed]

65. Miao, J.; Fan, Q.; Cui, L.; Li, J.; Li, J.; Cui, L. The malaria parasite Plasmodium falciparum histones: Organization, expression, and acetylation. Gene 2006, 369, 53-65. [CrossRef] [PubMed]

66. Kamakaka, R.T. Histone variants: Deviants? Genes Dev. 2005, 19, 295-316. [CrossRef] [PubMed]

67. Hoeijmakers, W.A.M.; Salcedo-Amaya, A.M.; Smits, A.H.; Françoijs, K.; Treeck, M.; Gilberger, T.; Stunnenberg, H.G.; Bártfai, R. H2A.Z/H2B.Z double-variant nucleosomes inhabit the AT -rich promoter regions of the P lasmodium falciparum genome. Mol. Microbiol. 2013, 87, 1061-1073. [CrossRef] [PubMed]

68. Petter, M.; Selvarajah, S.A.; Lee, C.C.; Chin, W.H.; Gupta, A.P.; Bozdech, Z.; Brown, G.V.; Duffy, M.F. H2A.Z and H2B.Z doublevariant nucleosomes define intergenic regions and dynamically occupyvargene promoters in the malaria parasite Plasmodium falciparum. Mol. Microbiol. 2013, 87, 1167-1182. [CrossRef] [PubMed]

69. Vanagas, L.; Contreras, S.M.; Angel, S.O. Apicomplexa and Histone Variants: What's New? In Chromatin and Epigenetics; Logie, C., Knoch, T.A., Eds.; IntechOpen: London, UK, 2020; ISBN 978-1-78984-493-1.

70. Fraschka, S.A.-K.; Henderson, R.W.M.; Bártfai, R. H3.3 demarcates GC-rich coding and subtelomeric regions and serves as potential memory mark for virulence gene expression in Plasmodium falciparum. Sci. Rep. 2016, 6, 31965. [CrossRef]

71. Hoeijmakers, W.A.M.; Flueck, C.; Françoijs, K.-J.; Smits, A.H.; Wetzel, J.; Volz, J.C.; Cowman, A.F.; Voss, T.; Stunnenberg, H.G.; Bártfai, R. Plasmodium falciparum centromeres display a unique epigenetic makeup and cluster prior to and during schizogony. Cell. Microbiol. 2012, 14, 1391-1401. [CrossRef]

72. Ay, F.; Bunnik, E.M.; Varoquaux, N.; Vert, J.-P.; Noble, W.S.; Le Roch, K.G. Multiple dimensions of epigenetic gene regulation in the malaria parasite Plasmodium falciparum. BioEssays 2015, 37, 182-194. [CrossRef]

73. Jenuwein, T.; Allis, C.D. Translating the Histone Code. Science 2001, 293, 1074-1080. [CrossRef] [PubMed]

74. Saraf, A.; Cervantes, S.; Bunnik, E.M.; Ponts, N.; Sardiu, M.E.; Chung, D.-W.D.; Prudhomme, J.; Varberg, J.M.; Wen, Z.; Washburn, M.P.; et al. Dynamic and Combinatorial Landscape of Histone Modifications during the Intraerythrocytic Developmental Cycle of the Malaria Parasite. J. Proteome Res. 2016, 15, 2787-2801. [CrossRef] [PubMed]

75. Salcedo-Amaya, A.M.; van Driel, M.A.; Alako, B.T.; Trelle, M.B.; Elzen, A.M.G.V.D.; Cohen, A.M.; Janssen-Megens, E.M.; van de Vegte-Bolmer, M.; Selzer, R.R.; Iniguez, A.L.; et al. Dynamic histone H3 epigenome marking during the intraerythrocytic cycle of Plasmodium falciparum. Proc. Natl. Acad. Sci. USA 2009, 106, 9655-9660. [CrossRef] [PubMed]

76. Coetzee, N.; Sidoli, S.; Van Biljon, R.; Painter, H.; Llinás, M.; Garcia, B.A.; Birkholtz, L.-M. Quantitative chromatin proteomics reveals a dynamic histone post-translational modification landscape that defines asexual and sexual Plasmodium falciparum parasites. Sci. Rep. 2017, 7, 1-12. [CrossRef] [PubMed]

77. Read, D.F.; Lu, Y.Y.; Cook, K.; Le Roch, K.; Noble, W.S. Predicting gene expression in the human malaria parasite Plasmo-dium falciparum. bioRxiv 2019, 431049. [CrossRef]

78. Segal, E.; Widom, J. What controls nucleosome positions? Trends Genet. 2009, 25, 335-343. [CrossRef]

79. Ponts, N.; Harris, E.Y.; Prudhomme, J.; Wick, I.; Eckhardt-Ludka, C.; Hicks, G.R.; Hardiman, G.; Lonardi, S.; Le Roch, K.G. Nucleosome landscape and control of transcription in the human malaria parasite. Genome Res. 2010, 20, 228-238. [CrossRef]

80. Ponts, N.; Harris, E.Y.; Lonardi, S.; Le Roch, K.G. Nucleosome occupancy at transcription start sites in the human malaria parasite: A hard-wired evolution of virulence? Infect. Genet. Evol. 2011, 11, 716-724. [CrossRef]

81. Westenberger, S.J.; Cui, L.; Dharia, N.; Winzeler, E.; Cui, L. Genome-wide nucleosome mapping of Plasmodium falciparum reveals histone-rich coding and histone-poor intergenic regions and chromatin remodeling of core and subtelomeric genes. BMC Genom. 2009, 10, 610-617. [CrossRef]

82. Chereji, R.V.; Kan, T.-W.; Grudniewska, M.K.; Romashchenko, A.V.; Berezikov, E.; Zhimulev, I.F.; Guryev, V.; Morozov, A.V.; Moshkin, Y.M. Genome-wide profiling of nucleosome sensitivity and chromatin accessibility in Drosophila melanogaster. Nucleic Acids Res. 2015, 44, 1036-1051. [CrossRef]

83. Mito, Y.; Henikoff, J.G.; Henikoff, S. Genome-scale profiling of histone H3.3 replacement patterns. Nat. Genet. 2005, 37, 1090-1097. [CrossRef] 
84. Ay, F.; Bunnik, E.M.; Varoquaux, N.; Bol, S.M.; Prudhomme, J.; Vert, J.-P.; Noble, W.S.; Le Roch, K.G. Three-dimensional modeling of the P. falciparum genome during the erythrocytic cycle reveals a strong connection between genome architecture and gene expression. Genome Res. 2014, 24, 974-988. [CrossRef] [PubMed]

85. Abel, S.; Le Roch, K.G. The role of epigenetics and chromatin structure in transcriptional regulation in malaria parasites. Brief. Funct. Genom. 2019, 18, 302-313. [CrossRef] [PubMed]

86. Hollin, T.; Gupta, M.; Lenz, T.; Le Roch, K.G. Dynamic Chromatin Structure and Epigenetics Control the Fate of Malaria Parasites. Trends Genet. 2021, 37, 73-85. [CrossRef]

87. Rowley, M.J.; Corces, V.G. The three-dimensional genome: Principles and roles of long-distance interactions. Curr. Opin. Cell Biol. 2016, 40, 8-14. [CrossRef] [PubMed]

88. Broadbent, K.M.; Broadbent, J.C.; Ribacke, U.; Wirth, D.F.; Rinn, J.L.; Sabeti, P.C. Strand-specific RNA sequencing in Plasmodium falciparum malaria identifies developmentally regulated long non-coding RNA and circular RNA. BMC Genom. 2015, 16, 1-22. [CrossRef]

89. Yin, S.; Fan, Y.; He, X.; Wei, G.; Wen, Y.; Zhao, Y.; Shi, M.; Wei, J.; Chen, H.; Han, J.; et al. The cryptic unstable transcripts are associated with developmentally regulated gene expression in blood-stage Plasmodium falciparum. RNA Biol. 2020, 17, 828-842. [CrossRef]

90. Amit-Avraham, I.; Pozner, G.; Eshar, S.; Fastman, Y.; Kolevzon, N.; Yavin, E.; Dzikowski, R. Antisense long noncoding RNAs regulate var gene activation in the malaria parasite Plasmodium falciparum. Proc. Natl. Acad. Sci. USA 2015, 112, E982-E991. [CrossRef]

91. Rinn, J.L.; Chang, H.Y. Genome Regulation by Long Noncoding RNAs. Annu. Rev. Biochem. 2012, 81, 145-166. [CrossRef]

92. Zhu, F.; Farnung, L.; Kaasinen, E.; Sahu, B.; Yin, Y.; Wei, B.; Dodonova, S.O.; Nitta, K.R.; Morgunova, E.; Taipale, M.; et al. The interaction landscape between transcription factors and the nucleosome. Nat. Cell Biol. 2018, 562, 76-81. [CrossRef]

93. Cortés, A.; Carret, C.; Kaneko, O.; Lim, B.Y.S.Y.; Ivens, A.; Holder, A.A. Epigenetic Silencing of Plasmodium falciparum Genes Linked to Erythrocyte Invasion. PLoS Pathog. 2007, 3, e107. [CrossRef]

94. Jiang, L.; Mu, J.; Zhang, Q.; Ni, T.; Srinivasan, P.; Rayavara, K.; Yang, W.; Turner, L.; Lavstsen, T.; Theander, T.G.; et al. PfSETvs methylation of histone H3K36 represses virulence genes in Plasmodium falciparum. Nat. Cell Biol. 2013, 499, 223-227. [CrossRef] [PubMed]

95. Ukaegbu, U.E.; Kishore, S.P.; Kwiatkowski, D.L.; Pandarinath, C.; Dahan-Pasternak, N.; Dzikowski, R.; Deitsch, K.W. Recruitment of PfSET2 by RNA Polymerase II to Variant Antigen Encoding Loci Contributes to Antigenic Variation in P. falciparum. PLoS Pathog. 2014, 10, e1003854. [CrossRef] [PubMed]

96. Coleman, B.I.; Skillman, K.M.; Jiang, R.H.; Childs, L.M.; Altenhofen, L.M.; Ganter, M.; Leung, Y.; Goldowitz, I.; Kafsack, B.F.; Marti, M.; et al. A Plasmodium falciparum Histone Deacetylase Regulates Antigenic Variation and Gametocyte Conversion. Cell Host Microbe 2014, 16, 177-186. [CrossRef] [PubMed]

97. Brancucci, N.M.; Bertschi, N.L.; Zhu, L.; Niederwieser, I.; Chin, W.H.; Wampfler, R.; Freymond, C.; Rottmann, M.; Felger, I.; Bozdech, Z.; et al. Heterochromatin Protein 1 Secures Survival and Transmission of Malaria Parasites. Cell Host Microbe 2014, 16, 165-176. [CrossRef]

98. Bryant, J.M.; Baumgarten, S.; Dingli, F.; Loew, D.; Sinha, A.; Claës, A.; Preiser, P.R.; Dedon, P.C.; Scherf, A. Exploring the virulence gene interactome with CRISPR/dC as9 in the human malaria parasite. Mol. Syst. Biol. 2020, 16, e9569. [CrossRef]

99. Merrick, C.J.; Jiang, R.H.Y.; Skillman, K.M.; Samarakoon, U.; Moore, R.M.; Dzikowski, R.; Ferdig, M.T.; Duraisingh, M.T. Functional Analysis of Sirtuin Genes in Multiple Plasmodium falciparum Strains. PLoS ONE 2015, 10, e0118865. [CrossRef]

100. Epp, C.; Li, F.; Howitt, C.A.; Chookajorn, T.; Deitsch, K.W. Chromatin associated sense and antisense noncoding RNAs are transcribed from the var gene family of virulence genes of the malaria parasite Plasmodium falciparum. RNA 2008, 15, 116-127. [CrossRef]

101. Filarsky, M.; Fraschka, S.A.; Niederwieser, I.; Brancucci, N.M.B.; Carrington, E.; Carrió, E.; Moes, S.; Jenoe, P.; Bártfai, R.; Voss, T.S. GDV1 induces sexual commitment of malaria parasites by antagonizing HP1-dependent gene silencing. Science 2018, 359, 1259-1263. [CrossRef]

102. Sinha, A.; Hughes, K.R.; Modrzynska, K.K.; Otto, T.D.; Pfander, C.; Dickens, N.J.; Religa, A.A.; Bushell, E.; Graham, A.L.; Cameron, R.; et al. A cascade of DNA-binding proteins for sexual commitment and development in Plasmodium. Nat. Cell Biol. 2014, 507, 253-257. [CrossRef]

103. Narlikar, G.J.; Fan, H.-Y.; Kingston, R.E. Cooperation between Complexes that Regulate Chromatin Structure and Transcription. Cell 2002, 108, 475-487. [CrossRef]

104. Iyer, L.M.; Anantharaman, V.; Wolf, M.Y.; Aravind, L. Comparative genomics of transcription factors and chromatin proteins in parasitic protists and other eukaryotes. Int. J. Parasitol. 2008, 38, 1-31. [CrossRef] [PubMed]

105. Croken, M.M.; Nardelli, S.C.; Kim, K. Chromatin modifications, epigenetics, and how protozoan parasites regulate their lives Trends Parasitol. 2012, 28, 202-213. [CrossRef]

106. Bartholomew, B. Regulating the Chromatin Landscape: Structural and Mechanistic Perspectives. Annu. Rev. Biochem. 2014, 83, 671-696. [CrossRef] [PubMed]

107. Erdel, F.; Krug, J.; Längst, G.; Rippe, K. Targeting chromatin remodelers: Signals and search mechanisms. Biochim. Biophys. Acta (BBA) Bioenerg. 2011, 1809, 497-508. [CrossRef] 
108. Rippe, K.; Schrader, A.; Riede, P.; Strohner, R.; Lehmann, E.; Langst, G. DNA sequence- and conformation-directed positioning of nucleosomes by chromatin-remodeling complexes. Proc. Natl. Acad. Sci. USA 2007, 104, 15635-15640. [CrossRef] [PubMed]

109. Clapier, C.R.; Iwasa, J.; Cairns, B.R.; Peterson, C.L. Mechanisms of action and regulation of ATP-dependent chromatin-remodelling complexes. Nat. Rev. Mol. Cell Biol. 2017, 18, 407-422. [CrossRef] [PubMed]

110. Narlikar, G.J.; Sundaramoorthy, R.; Owen-Hughes, T. Mechanisms and Functions of ATP-Dependent Chromatin-Remodeling Enzymes. Cell 2013, 154, 490-503. [CrossRef]

111. Oppikofer, M.; Bai, T.; Gan, Y.; Haley, B.; Liu, P.; Sandoval, W.; Ciferri, C.; Cochran, A.G. Expansion of the ISWI chromatin remodeler family with new active complexes. EMBO Rep. 2017, 18, 1697-1706. [CrossRef] [PubMed]

112. Flaus, A. Identification of multiple distinct Snf2 subfamilies with conserved structural motifs. Nucleic Acids Res. 2006, 34, 2887-2905. [CrossRef]

113. Corona, D.F.V.; Siriaco, G.; Armstrong, J.A.; Snarskaya, N.; McClymont, S.A.; Scott, M.P.; Tamkun, J.W. ISWI Regulates HigherOrder Chromatin Structure and Histone H1 Assembly In Vivo. PLoS Biol. 2007, 5, e232. [CrossRef]

114. Strohner, R.; Wachsmuth, M.; Dachauer, K.; Mazurkiewicz, J.; Hochstatter, J.; Rippe, K.; Längst, G. A 'loop recapture' mechanism for ACF-dependent nucleosome remodeling. Nat. Struct. Mol. Biol. 2005, 12, 683-690. [CrossRef] [PubMed]

115. Dechassa, M.L.; Sabri, A.; Pondugula, S.; Kassabov, S.R.; Chatterjee, N.; Kladde, M.P.; Bartholomew, B. SWI/SNF Has Intrinsic Nucleosome Disassembly Activity that Is Dependent on Adjacent Nucleosomes. Mol. Cell 2010, 38, 590-602. [CrossRef]

116. Ren, J.; Briones, V.; Barbour, S.; Yu, W.; Han, Y.; Terashima, M.; Muegge, K. The ATP binding site of the chromatin remodeling homolog Lsh is required for nucleosome density and de novo DNA methylation at repeat sequences. Nucleic Acids Res. 2015, 43, 1444-1455. [CrossRef] [PubMed]

117. Myant, K.; Stancheva, I. LSH Cooperates with DNA Methyltransferases to Repress Transcription. Mol. Cell. Biol. 2007, 28, 215-226. [CrossRef] [PubMed]

118. Ocampo, J.; Chereji, R.V.; Eriksson, P.R.; Clark, D.J. The ISW1 and CHD1 ATP-dependent chromatin remodelers compete to set nucleosome spacingin vivo. Nucleic Acids Res. 2016, 44, 4625-4635. [CrossRef] [PubMed]

119. Pointner, J.; Persson, J.; Prasad, P.; Norman-Axelsson, U.; Strålfors, A.; Khorosjutina, O.; Krietenstein, N.; Svensson, J.P.; Ekwall, K.; Korber, P. CHD1 remodelers regulate nucleosome spacingin vitroand align nucleosomal arrays over gene coding regions inS. pombe. EMBO J. 2012, 31, 4388-4403. [CrossRef]

120. Hoffmeister, H.; Fuchs, A.; Erdel, F.; Pinz, S.; Gröbner-Ferreira, R.; Bruckmann, A.; Deutzmann, R.; Schwartz, U.; Maldonado, R.; Huber, C.; et al. CHD3 and CHD4 form distinct NuRD complexes with different yet overlapping functionality. Nucleic Acids Res. 2017, 45, 10534-10554. [CrossRef]

121. Bowen, N.J.; Fujita, N.; Kajita, M.; Wade, P.A. Mi-2/NuRD: Multiple complexes for many purposes. Biochim. Biophys. Acta (BBA) Gene Struct. Expr. 2004, 1677, 52-57. [CrossRef]

122. Morrison, A.J.; Shen, X. Chromatin remodelling beyond transcription: The INO80 and SWR1 complexes. Nat. Rev. Mol. Cell Biol. 2009, 10, 373-384. [CrossRef]

123. Heyer, W.-D.; Li, X.; Rolfsmeier, M.; Zhang, X.-P. Rad54: The Swiss Army knife of homologous recombination? Nucleic Acids Res. 2006, 34, 4115-4125. [CrossRef]

124. Unk, I.; Hajdú, I.; Blastyák, A.; Haracska, L. Role of yeast Rad5 and its human orthologs, HLTF and SHPRH in DNA damage tolerance. DNA Repair 2010, 9, 257-267. [CrossRef] [PubMed]

125. Svejstrup, J.Q. Rescue of arrested RNA polymerase II complexes. J. Cell Sci. 2003, 116, 447-451. [CrossRef]

126. Diermeier, S.; Kolovos, P.; Heizinger, L.; Schwartz, U.; Georgomanolis, T.; Zirkel, A.; Wedemann, G.; Grosveld, F.; Knoch, T.A.; Merkl, R.; et al. TNF $\alpha$ signalling primes chromatin for NF- $\mathrm{kB}$ binding and induces rapid and widespread nucleosome repositioning. Genome Biol. 2014, 15, 1-13. [CrossRef]

127. Ji, D.D.; Arnot, D.E. A Plasmodium falciparum homologue of the ATPase subunit of a multi-protein complex involved in chromatin remodelling for transcription. Mol. Biochem. Parasitol. 1997, 88, 151-162. [CrossRef]

128. Sullivan, W.J.; Monroy, M.A.; Bohne, W.; Nallani, K.C.; Chrivia, J.; Yaciuk, P.; Smith, C.K.; Queener, S.F. Molecular cloning and characterization of an SRCAP chromatin remodeling homologue in Toxoplasma gondii. Parasitol. Res. 2003, 90, 1-8. [CrossRef]

129. Dabney, J.; Meyer, M. Length and GC-biases during sequencing library amplification: A comparison of various polymerase-buffer systems with ancient and modern DNA sequencing libraries. Biotechniques 2012, 52, 87-94. [CrossRef] [PubMed]

130. Spitz, F.; Furlong, E.E.M. Transcription factors: From enhancer binding to developmental control. Nat. Rev. Genet. 2012, 13, 613-626. [CrossRef]

131. Kubik, S.; O’Duibhir, E.; de Jonge, W.J.; Mattarocci, S.; Albert, B.; Falcone, J.-L.; Bruzzone, M.J.; Holstege, F.C.; Shore, D. SequenceDirected Action of RSC Remodeler and General Regulatory Factors Modulates +1 Nucleosome Position to Facilitate Transcription. Mol. Cell 2018, 71, 89-102.e5. [CrossRef] [PubMed] 